\title{
COLLINS v. THE QUEEN: FURTHER JURISPRUDENCE ON SECTION 24(2) OF THE CHARTER
}

\author{
Bruce P. Elman*
}

\section{INTRODUCTION}

It has long been an axiom of law that rights are meaningless without adequate remedies.' Indeed the single greatest reason for the impotence of the Canadian Bill of Rights was the lack of a remedies section. The failure to provide for adequate remedies for breaches of the provisions of the Canadian Bill of Rights provided much of the impetus for the movement to entrench a Charter of Rights in our Constitution. Commenting on the lack of an enforcement section in the Canadian Bill of Rights, Professor Walter Tarnopolsky (as he then was) stated:2

Ordinarily one would expect that when a Bill of Rights sets out certain rights and freedoms, that a remedy would be presumed. In other words, our Courts would not be moved to assert there is a right unless there is a remedy ... the majority of our Supreme Court has not followed that kind of logical conclusion. In the Hogan case, although all members of the Supreme Court did say that the denial of counsel to Hogan was a contravention of the right to counsel in the Canadian Bill of Rights, the majority went on to say that there was not a remedy written out in the Bill of Rights and they did not have to devise one, and certainly they saw no reason to adopt the American exclusionary rule because, they said, the system in the United States was different.

Although originally Bill C- 60 , the forerunner of the Charter, granted the Courts only limited remedial powers to rectify breaches of Charter rights, ${ }^{3}$ ultimately the Charter evolved to include the present section $24 .^{4}$ It provides:

(1) Anyone whose rights or freedoms as guaranteed by this Charter, have been infringed or denied may apply to a court of competent jurisdiction to obtain such remedy as the court considers appropriate and just in the circumstances.

(2) Where in proceedings under subsection (1), a court concludes that evidence was obtained in a manner that infringed or denied any rights or freedoms as guaranteed by this Charter, the evidence shall be excluded if it is established that, having regard to all the

- Of the Faculty of Law at the University of Alberta, Edmonton.

1. See Dicey, Introduction to the Study of the Law of the Constitution (10th Edition by E.C.S. Wade) at 198, 203. Also see, H.W. Jones, "The Rule of Law and the Welfare State", 58 Colum. L. Rev. 143. Professor Jones restates Dicey's third element of the "rule of law" as follows: ". . . effective judicial remedies are more important than abstract constitutional declarations in securing the rights of the individual against encroachment by the state." (at 150).

2. Proceedings of the Special Joint Committee on the Consitution of Canada (1980-81) No. 7 at 15.

3. Bill C-60, An Act to Amend the Constitution of Canada, was introduced by the Trudeau Government in June of 1978. See Canada, House of Commons, Bill C-60, 3rd Session, 30th Parliament, 26-27 Eliz. II, 1977-78. It included the following enforcement provision:

24. Where no other remedy is available or is provided by law, any individual may, in accordance with the applicable procedure of any court in Canada of competent jurisdiction, request the court to define or enforce any of the individual rights and freedoms declared by this Charter, as they extend or apply to him or her, by means of a declaration of the court or by means of an injunction or similar relief, accordingly as the circumstances require.

4. For a fuller discussion of the history of section 24, see McLellan and Elman, "The Enforcement of the Canadian Charter of Rights and Freedoms: An Analysis of Section 24" (1983) 21 Alta. L. Rev. 205 at $206-208$.

5. Constitution Act, 1982. 
circumstances, the admission of it in the proceedings would bring the administration of justice into disrepute.

These provisions broadened the general remedial power and provided for the remedy of the exclusion of evidence in subsection (2). They seemed to answer the concerns of civil libertarians. However, the decision of the British Columbia Court of Appeal in Collins v. The Queen ${ }^{6}$ was of great concern to the supporters of the Charter.

\section{THE FACTS}

The facts in the Collins case are, apparently, unremarkable, at least in British Columbia. Ruby Collins and her husband, Richard, had been under surveillance by constables from the R.C.M.P. Drug Squad. At 2:50 p.m., Ruby Collins was observed in a tavern in Gibsons, British Columbia, in the company of two other persons. At 3:35 p.m. they were joined by Richard Collins and another person. Shortly thereafter, Richard and one of the others left the tavern. They were followed by the R.C.M.P. officers and subsequently arrested. Richard Collins was searched and a quantity of heroin was found.

At 4:15 p.m. the officers returned to the pub and observed Ruby Collins in the company of another woman at a different table. One officer approached her at a quickened pace, grabbed her by the throat to prevent her swallowing anything that might be in her mouth, and identified himself as a police officer. In doing so, the officer used considerable force. In the process of applying the choke-hold procedure, the constable noticed a green item in Ruby Collins' hand. He told her to drop the item on the floor. She did so. The item seized was a green balloon containing heroin.

Ruby Collins was charged with possession of heroin for the purpose of trafficking. At trial, ${ }^{7}$ County Court Judge Wong held that the search was unlawful and unreasonable and, therefore, a contravention of section $\mathbf{8}$ of the Charter. ${ }^{8}$

However, relying on the judgment of the Supreme Court of Canada in Rothman v. The Queen, ${ }^{9}$ Judge Wong held that the defendant had failed to satisfy him that the evidence should be excluded pursuant to section 24(2) of the Charter. The evidence was admitted and Ruby Collins was found guilty. Ruby Collins appealed to the British Columbia Court of Appeal.

\section{THE COURT OF APPEAL DECISION}

Ruby Collins' appeal to the British Columbia Court of Appeal was unanimously dismissed. Chief Justice Nemetz ${ }^{10}$ basically followed the reasoning of Judge Wong. The Chief Justice held that, on the evidence presented, the Trial Judge was not wrong in finding that the search was

6. [1983] 5 W.W.R. 43, 148 D.L.R. (3d) 40, 5 C.C.C. (3d) 141. All future references will be to the report at 5 C.C.C. (3d) 141.

7. See [1983] W.C.D. 061, [1983] B.C.W.L.D. 1180.

8. As we will see, infran. 22 and accompanying text, this decision may have been the result of an unusual occurence during the testimony of the arresting officer.

9. [1981] 1 S.C.R. 640.

10. Supra n. 6 at $143-147$. 
unreasonable. Further, his Lordship agreed that the evidence should not be excluded. Chief Justice Nemetz concluded:"1

Without justifying the use of the throat hold as a general practice, I cannot say that the judge erred in the circumstances of this case.

Justice Seaton, ${ }^{12}$ on the other hand, disagreed with Judge Wong's finding that the search was unreasonable. However, his Lordship held that, in any event, the evidence was admissible. In the course of Justice Seaton's judgment, he advanced the following propositions: Firstly, ${ }^{13}$

... it is not open to a court in Canada to exclude evidence in order to discipline the police. We are only to exclude evidence to avoid the administration of justice being brought into disrepute.

\section{It follows from this proposition that ${ }^{14}$}

It is the admission, not the obtaining, that is the focus of attention, though the manner of obtaining the evidence is one of the circumstances.

Thirdly, ${ }^{15}$

Evidence improperly obtained is prima facie admissible. The onus is on the person who wishes the evidence excluded to establish the further ingredient: that the admission of the evidence would bring the administration of justice into disrepute.

Finally, on the question of whether there is a discretion embodied in section 24(2), Justice Seaton stated:16

Nothing in s. 24(2) suggests a discretion. If it is established that admission of the evidence would bring the administration of justice into disrepute 'the evidence shall be excluded'. There is only the one test. When it is passed, the evidence is excluded. If it is not passed, the evidence is admitted. There is no basis for any other test, or for the exercise of a discretion.

Applying these propositions Justice Seaton endorsed the reasoning of the Trial Judge and dismissed the appeal. ${ }^{17}$

Craig J.A., in a separate judgment, also upheld the trial judge's ruling.

Ruby Collins appealed to the Supreme Court of Canada. In a recent judgment, her appeal was allowed, in part, and a new trial was ordered. ${ }^{18}$

\section{THE SUPREME COURT DECISION}

Justice Lamer, speaking for the majority, identifies the two issues confronting the Court: ${ }^{19}$

1) was the search conducted by the police officer unreasonable?

11. Id. at 146.

12. Id. at $147-155$.

13. Id. at 150.

14. Id. at 150.

15. Id. at 150.

16. Id. at 151.

17. Portions of the Trial Judge's reasoning are reproduced by Seaton J.A., Id. at 148 - 149. After examining the Rothman decision, the Trial Judge, in part, stated: "Turning now to the case at bar, would any ordinary, right-thinking person think that seizing and searching a suspected hard drug trafficker for possession of illicit drugs be shocking to the community? The answer is self-evident. ... I have concluded that, having regard to all the circumstances of this case, police conduct here is not shocking such that the admission of the evidence . . . would necessarily cast the administration of justice into disrepute. Accordingly, the evidence will be admitted. (at 149.)

18. See Collins v. The Queen, Supreme Court of Canada, File number 17937, April 9, 1987.

19. Id. at 10. 
2) if so, having regard to all the circumstances, would the admission of the evidence bring the administration of justice into disrepute?

\section{A. WAS THE SEARCH UNREASONABLE?}

At the outset, Justice Lamer expresses his general agreement with the propositions advanced by Justice Seaton in his judgment in the Court of Appeal. ${ }^{20}$ Then, his Lordship begins his discussion of the first issue by noting that the applicant (usually the accused) bears the burden of persuading the court that her rights have been infringed or denied. However, where there has been a warrantless search, the burden shifts to the prosecution to show on the balance of probabilities that the search was reasonable. In order for a search to be reasonable, it must be authorized by law, the law itself must be reasonable, and the manner in which the search is carried out must be reasonable.

In the Collins case the Crown, relying on section 10 of the Narcotics Control Act, had to establish that the officer believed, on reasonable grounds, that there was a narcotic in the place where the person searched was found. Further, the nature of the belief will determine whether the manner in which the search was conducted was reasonable. Therefore, as Justice Lamer points out, very specific information will be necessary before a choke hold will be held to be reasonable. ${ }^{21}$

A curious problem arose in the trial of Ruby Collins. Crown counsel was attempting to show the reasonable basis for the constable's belief that a narcotic was present when defence counsel objected to the line of questioning on the grounds that it would elicit hearsay testimony. It is unclear from the record whether the trial judge upheld the objection or simply failed to rule on it. In any event, Crown counsel halted the line of questioning and, consequently, failed to establish the reasonableness of the constable's belief. ${ }^{22}$

The search, therefore, was found to be unreasonable. Because the defence counsel's objection was unfounded, ${ }^{23}$ Justice Lamer and the majority of the court decided that the matter should be sent back for a new trial. However, first the Court had to decide whether the evidence should have been excluded pursuant to section 24(2), assuming the present trial record were to stand. ${ }^{24}$

20. Id. at 7-8. To refresh one's memory of these propositions, see supra $\mathrm{nn}$. 13-16 and accompanying text.

21. Id. at $11-12$. Lamer $\mathrm{J}$. goes on to state that if there are reasonable grounds to believe that the person searched is a "drug handler", then the throat hold will not be unreasonable.

22. It is clear that the constable's suspicions as to the presence of narcotics were not aroused by observation of Mrs. Collins.

23. It would appear, on the basis of the Supreme Court of Canada decision in Eccles v. Bourque et al. [1975] 2 S.C.R. 739, (1974) 19 C.C.C. (2d) 129, 50 D.L.R. (3d) 753, that reasonable and probable grounds can be based on hearsay.

24. If, on the present record, the evidence should not have been excluded, i.e. if the Trial Judge did not err on the question of exclusion, there would be no reason to send the matter back for a re-trial. 


\section{B. WOULD THE ADMISSION OF EVIDENCE BRING THE ADMIN- ISTRATION OF JUSTICE INTO DISREPUTE?}

Justice Lamer, therefore, went on to consider the second question, namely:

.. . having regard to all the circumstances, would the admission of the evidence bring the administration of justice into disrepute?

Justice Lamer begins this section of his judgment with a brief discussion of the social policy concerns underlying section $24(2)$ of the Charter. He notes that the focus of the inquiry is on the point in the process where the Crown seeks to have the unconstitutionally obtained evidence admitted at the trial. Thus it follows that the focus of the inquiry is not on the conduct of the police officers. His Lordship states: ${ }^{25}$

\footnotetext{
Misconduct by the police in the investigatory process often has some effect on the repute of the administration of Justice, but s. 24(2) is not a remedy for police misconduct, requiring the exclusion of the evidence if, because of this misconduct, the administration of justice was brought into disrepute. . . . the purpose of s. 24(2) is to prevent having the administration of justice brought into further disrepute by the admission of the evidence in the proceedings.
}

In elaborating on this point Justice Lamer notes that it will also be necessary to consider any disrepute that may arise from the exclusion of evidence.

Disrepute naturally involves a consideration of the community views. How should the court go about assessing these views? Justice Lamer rejects the suggestion that public opinion polls should be examined. His Lordship emphasizes the anti-majoritarian nature of the Charter. Justice Lamer adopts the test proposed by Professor Morrisette:26

\footnotetext{
Would the admission of the evidence bring the administration of justice into disrepute in the eyes of the reasonable man, dispassionate and fully apprised of the circumstances of the case?
}

\section{Justice Lamer adds: ${ }^{27}$}

The reasonable person is usually the average person in the community, but only when the community's mood is reasonable.

Consequently, according to Justice Lamer, the decision of whether to exclude unconstitutionally obtained evidence is not left to the "untramelled discretion" of the Trial Judge. ${ }^{28}$

The Charter directs the court to consider "all the circumstances" in determining whether the admission of the evidence would bring the administration of Justice into disrepute. Justice Lamer identifies three factors of overriding importance:

1. FAIRNESS OF THE TRIAL: If the admission of the evidence will affect the fairness of the trial, then admitting the evidence in the proceeding would tend to bring the administration of justice into disrepute. In this context, Justice Lamer draws a distinction between real evidence - evidence that

25. Supra n. 18 at 14.

26. Morrisette, "The Exclusion of Evidence under the Canadian Charter of Rights and Freedoms: What to Do and What Not to Do" (1984) 29 McGill L.J. 521 at 533.

27. Supra n. 18 at 16.

28. Id. 
existed irrespective of the Charter violation - and selfincriminatory evidence - that which may have been created out of a breach of the Charter right. ${ }^{29}$

2. SERIOUSNESS OF THE CHARTER VIOLATION: This inquiry focuses on the disrepute which will result from the judicial condonation of the police misconduct by the acceptance of the evidence. Justice Lamer notes that the failure to proceed properly when the option is available tends to indicate a blatant disregard for the Charter which would support the exclusion of the evidence..$^{30}$

3. EFFECT OF EXCLUSION: It is necessary to consider any disrepute that will result from exclusion of the evidence. It is in this inquiry that the seriousness of the offence will be considered..$^{31}$

Finally, Justice Lamer addresses the applicability of the "community shock test" which he enunciated in the Rothman case. ${ }^{32}$ Referring to the test, his Lordship states: ${ }^{33}$

That is a very high threshold, higher, in my view than that to be attained to bring the administration into disrepute in the context of a violation of the Charter.

A lower threshold is required, according to Justice Lamer, because the Charter is the "most important law in the land" and because of the more lenient wording of the French version of section $24(2){ }^{34}$ The words "would bring the administration of Justice into disrepute" are translated in the French text as "est susceptible de deconsiderer l'administration de la justice". The phrase "est susceptible de" translates as "could" (implying a possibility) as opposed to the English version "would" (which implies either a certainty or, at least, a probability). Thus the French version of section 24(2) places an easier burden on the applicant, a burden inconsistent with the rather stringent requirements of the "community shock test".

Applying the foregoing law to the facts, Justice Lamer holds that, although there is nothing to suggest that the admission of the evidence would create an unfair trial and in spite of the fact that the cost of excluding the evidence is relatively high, the evidence must be excluded because of the flagrant violation of the rights of the accused due to the misconduct of the police. He states that the Court must "dissociate itself from the conduct of the police in this case". ${ }^{35}$

29. Id. at $18-19$.

30. Id. at $19-20$.

31. Id. at $20-21$.

32. It will be remembered that the "community shock test" was the basis of Judge Wong's decision not to exclude the evidence in the Collins case. Further, the appropriateness of this test, as an integral part of Judge Wong's reasoning, was affirmed by the British Columbia Court of Appeal. It should be noted, however, that Justice McIntyre, in his dissenting judgment, asserts that Justice Seaton adopted a test akin to the "resonable man test" proposed by Professor Morrisette and not the "community shock test".

33. Supran. 18 at $21-22$.

34. Pursuant to section 57 of the Constitution Act, 1982, the English and French versions are equally authoritative.

35. Supran. 18 at 23. 
Justice Le Dain concurred in result although not in all propositions advanced by Justice Lamer. Justice McIntyre dissented on the issue of the exclusion of the evidence. His Lordship held that the evidence should have been admitted.

\section{DISCUSSION}

Justice Lamer's decision in Collins makes a significant statement on the interpretation of section 24(2) of the Charter. Some comments on aspects of the judgment follow:

\section{A. COMMUNITY SHOCK TEST}

The rejection of the "community shock test" is an important advance in the protection of civil liberties. In a study of exclusion rates in 120 cases, reported in the Canadian Criminal Cases and the Canadian Rights Reporter, it was found that the exclusion rate for cases using the "community shock test" was substantially lower than the rate in cases which did not use the test. ${ }^{36}$

The "community shock test" is an inappropriate test for the determination of when evidence obtained in breach of the Charter should be excluded. It should be remembered that the "community shock test" was first enunciated by Justice Lamer in the Rothman case. That case involved the admissibility of a confession made to an undercover police officer in the cells. Justice Lamer proposed the test in a concurring judgment. Furthermore, the test was not the subject of comment by the majority. More importantly, Justice Lamer was not adjudicating a case involving constitutionally protected rights. If the rights protected by the Charter should be given a large and liberal interpretation ${ }^{37}$ consistent with their position as the supreme law of the land, ${ }^{38}$ the same large and liberal interpretation should be given to the provisions which guarantee remedies for the infringement of those rights. A restrictive test such as the "community shock test" would be inconsistent with the Charter's consitutional status.

Further, as Justice Lamer points out, the "community shock test" would also be inconsistent with the French version of the Charter. As noted earlier, the French version of the Charter provides a more liberal test than does its English counterpart. As both are of equal authority, it is important that a restrictive test such as "community shock" not be superimposed on section 24(2) to give it a meaning at odds with the general tenor of the French version.

In Regina v. Therens Justice Le Dain suggested that the "community shock test" was inappropriate for section 24(2) applications. ${ }^{39}$ It is interesting to note that the use of the "community shock test" declined in

36. See Hittel and Ross, Exclusion of Evidence Under Section 24(2) of the Charter: A Statistical Analysis (1982 - 1986), Unpublished Paper, March 30, 1987.

37. See Law Society of Upper Canada v. Skapinker (1984) 9 D.L.R. (4th) 161 (S.C.C.), Hunterv. Southam, Inc. (1984) 11 D.L.R. (4th) 641 (S.C.C.), R. v. Big M Drug Mart (1985) 18 D.L.R. (4th) 321 (S.C.C.).

38. See section 52(1) of the Constitution Act 1982.

39. (1985) 45 C.R. (3d) 97 (S.C.C.) at 132. 
the fourth and fifth years after the Charter came into effect. ${ }^{40}$ The decision in Collins should put the test to rest, at least in Charter cases.

\section{B. JUDICIAL DISCRETION}

A second comment must be made on the notion, advanced by Justice Lamer, that the "reasonable, dispassionate, and fully aware man test" is antithetical to the exercise of judicial discretion. Nothing could be further from the truth. Concepts such as the "reasonable man test" are nothing more than a code for the balancing of different policy interests. Such allegedly objective standards mask a decision-making process that, at its core, is infused with the personal perspectives and preferences of the judge who is undertaking the balancing of the relevant policy concerns.

Lord Denning, speaking about certain tort concepts, recognized this truth: ${ }^{41}$

The truth is that all these three, duty, remoteness and causation, are all devices by which
the courts limit the range of liability for negligence or nuisance. ... All these devices are
useful in their way. But ultimately it is a question of policy for judges to decide.

Similarly, whether evidence should be excluded for a breach of a Charter right is a question which judges must decide. Further, at first instance at least, they will decide these questions based upon their personal perceptions of the relevant policy issues. Consequently, judges will often differ in result. A case in point occurs in the Collins case, itself. Here both Justice Lamer and Justice McIntyre apply the same test, the "reasonable dispassionate man test". Yet Justice Lamer would have excluded the evidence while Justice McIntyre would have admitted it.

This only points up that which we all know: any test such as the "reasonable dispassionate man test" is not a formula which produces precise results. Rather it is a door of opportunity for the exercise of judicial discretion. Thus the results are crude and uneven. It may be a useful phrase, but only so far as we understand the decision-making process that lies behind it.

\section{DISCIPLINING THE POLICE}

What are the policy considerations involved in making a decision whether to admit or exclude evidence? According to Justice Lamer, of prime concern is the integrity of the judicial process, i.e. that point in the administration of justice where the evidence is offered to the court as opposed to the point at which the evidence is gathered. Thus section 24(2) is not designed to discipline the police, or, phrased differently, to be a remedy for police misconduct.

Should this be so? It is arguable that it should not. Indeed, it is arguable that the disciplining of the police should be an important policy consideration when judges make decisions on section 24(2) applications. One of the goals of "discipline", if not the prime goal, should be to modify behaviour. Clearly our courts should not make decisions which foster or encourage

40. See Hittel and Ross, supra n. 36. This seems to coincide with the Supreme Court decision in Therens infra n. 43.

41. Lamb v. London Borough of Camden [1981] 2 All E.R. 408 at 413 - 414. 
behaviour on the part of the police which contravenes the Charter. The goal should be to modify police behaviour so that it conforms with the requirements of the Charter. One cannot rely on the public or the legislators to provide the necessary incentive. Justice Lamer has recognized that fundamental rights can never be majoritarian-based. It is the courts that must and should provide the incentive for the police to act in a constitutional manner.

Furthermore, it seems inevitable that police behaviour will be modified by decisions to admit or exclude evidence..$^{42}$ For example, in the Collins case, itself, the evidence of the heroin was excluded. This was despite the fact that the case was a serious one (possession of a narcotic for the purpose of trafficking) and the price of exclusion of the evidence was high, i.e. the potential acquittal of a person found in possession of a significant quantity of heroin. Yet the evidence, on the facts as disclosed in the transcript, should have been excluded. Why? The exclusion was based entirely upon the seriousness of the Charter violation. The misconduct of the police necessitated the court dissociating itself from their behaviour. One would expect the decision to alter the police use of choke-holds.

A second example may add weight to this argument. The first four cases heard by the Supreme Court of Canada involved a violation of section 10(b) of the Charter (Right to Counsel).$^{43}$ In all cases the Court decided that the unconstitutionally obtained evidence should have been excluded. Indeed, the Clarkson case involved a charge of murder and the exclusion of the evidence (statements made to the police) resulted in an acquittal of the accused. The cumulative effect of these cases must have been to impart, at the very least, the notion that the Supreme Court views a violation of section 10 (b) with a great deal of concern and that such a violation will in the vast majority of cases, including those of a serious nature, result in the exclusion of evidence. One would assume that police forces, interested in convictions, would ensure that the accused's right to counsel is adequately provided to him.

It may even be argued that Justice Lamer recognized the conditioning effect the admission or exclusion of evidence would have on police behaviour. His Lordship alludes to this when he notes: ${ }^{44}$

... it must be emphasized that even though the inquiry under s. 24(2) will necessarily focus on the specific prosecution, it is the long-term consequences of regular admission or exclusion of this type of evidence on the repute of the administration of justice which must be considered.

It might well be suggested that one long-term consequence which may effect the repute of the justice system is whether the courts are successful in compelling the police to behave in conformity to the requirements of the Charter.

Finally, "good faith" plays an important part in this issue. It may be argued that there is no rational reason for disciplining those who act in "good faith". Thus, where the police have acted in "good faith" there will

42. This question is of an empirical nature and awaits examination.

43. SeeR. v. Therens (1985) 45 C.R. (3d) 97, Rahn v. The Queen (1984) 45 C.R. (3d) 134, Traskv. The Queen (1985) 45 C.R. (3d) 137, Clarkson v. The Queen [1986] 1 S.C.R. 383.

44. Supra n. 18 at 15. 
most likely be no need to provide the remedy of exclusion of evidence for their misconduct. This appears to be the rationale behind the Supreme Court's decisions in Hamill v. The Queen, ${ }^{45}$ and Sieben v. The Queen.$^{46}$ Both involved "good faith" use of a writ of assistance to search for and seize narcotics. In both cases the evidence had been admitted and the appeals by the accuseds were dismissed.

\section{CONCLUSION}

Collins v. The Queen is an important case in our developing jurisprudence on section $24(2)$ of the Charter. Justice Lamer's judgment has spelled out the policy concerns, which he perceives to be at the heart of section 24(2). Further, his Lordship has brought some order to the factors to be considered in determining whether the admission of the evidence could bring the administration of justice into disrepute. Justice Lamer has adopted the more lenient French text in preference to the English text and has rejected the "shock the community test" which he first proposed in Rothman. Finally, his Lordship has placed an objective test on a section whose text has the potential for broad untrammelled judicial discretion. Whether this "reasonable, dispassionate man test" succeeds in holding judicial discretion in check remains to be seen. Only as successive cases unfold will we be able to plot the parameters of the test.

45. Unreported decision, File No. 18983, April 9, 1987.

46. Unreported decision, File No. 19109, April 9, 1987. 